\title{
SEISMIC RESPONSE OF REINFORCED CONCRETE SILOS
}

\author{
Rajani S Togarsi \\ Asst. Professor, Department of Civil Engineering, KLS GIT Belagavi, Karnataka, India
}

\begin{abstract}
Silos are the stack-like structures that are more commonly used for bulk storage of grain, coal, cement, carbon black, woodchips, food products and sawdust. As the density, flow and friction properties of stored material vary, the loads applied on silo structure and associated load carrying system also vary. In this paper reinforced concrete silo supported with shear walls and supported on only columns are considered with same dimensions. These two silos are modeled using Finite Element Method package software SAP 2000.These are molded for the soil type II situated in the zone II when silo is empty, partially filled and fully filled with storage material. These models are analysed for load combination 1.5(DL+IL) according to IS 1893 (Part-I) : 2002 and then response of reinforced concrete silo with shear wall and without shear walls has been determined in terms of Lateral displacement. The results reveal the effect of stored material on non-linear seismic behavior of Reinforced Concrete Silo.
\end{abstract}

Key words: Silo, Clinker, FEM

\section{INTRODUCTION}

Silos are used for storing different types of granular as well as powdery materials which are subjected to many different unconventional loading conditions which result in unusual failure modes. Silo failure have alerted design engineers to the danger of designing silos for only static pressures due to stored material at rest. Those failures have inspired wide spread research into the variation of pressures and flow materials into the Silo. The silo is designed according IS 1893 (Part-I) : 2002 considering clinker as the storage material.

\section{MODELLING AND ANALYSIS}

In this present study a friendly user FEM software package SAP 2000 is used. Here two reinforced concrete silo models with only columns and with shear wall are considered when the Silo is fully filled with storage material. Clinker is considered as granular storage material with density 16.50 $\mathrm{kN} / \mathrm{m} 3$. Gravity load analysis and lateral load analysis is carried out as per the seismic code 1893 (Part I): 2002 are carried out for both reinforced concrete silo models and an effort is made to study the effect of seismic load on them. Design data considered for the Silo are given in appendix. The silo consists of 1) Cylindrical wall, hopper bottom, curved beams on top and bottom, columns and Cylindrical wall, hopper bottom, curved beams on top and bottom, columns with shear wall. Cylindrical walls are modeled as shell element. Columns and curved beams provided at top and bottom are modeled as frame element. Curved beams are modeled as rigid diaphragms. The beam column joints are assumed to be rigid.

In this dissertation two distinct models of silo are considered are shown in fig 1 and 2.

MODEL I - Reinforced Concrete Silo elevated on Columns. MODEL II - Reinforced Concrete Silo elevated on Shear Wall.
$* * *$

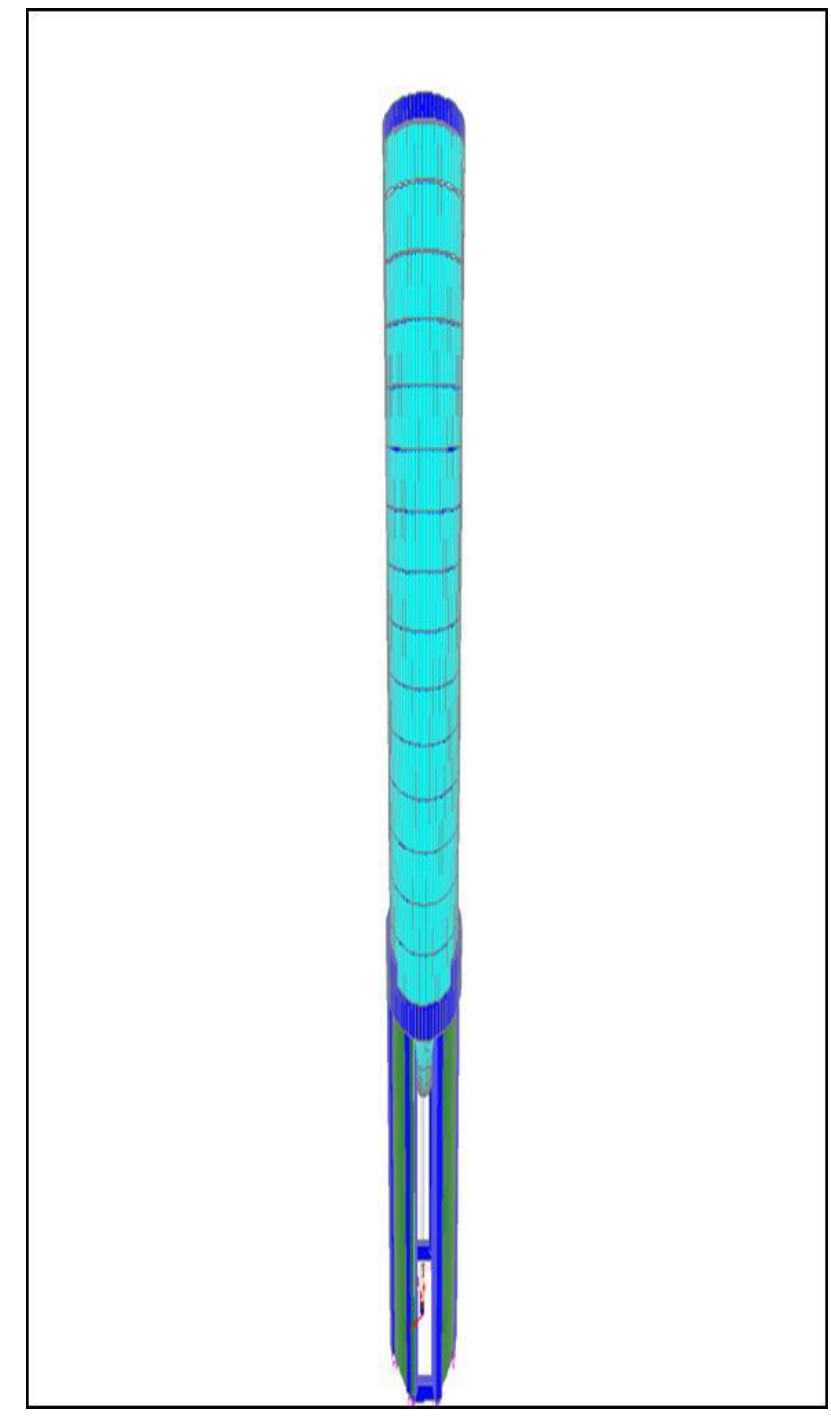

Fig 1. Reinforced Concrete Silo supported on columns only (MODEL I) 
Model I is the Reinforced Concrete Silo model elevated on columns in which silo walls are modeled as shell element and 8 columns are provided each at a radial distance of 450 of length $9 \mathrm{~m}$. A Plinth beam is provided at $1 \mathrm{~m}$ above the ground surface to provide connectivity between the columns. Model II is the Reinforced Concrete Silo model elevated on Shear wall. In this model silo walls as well as shear walls are modeled as shell element and 8 columns are provided each at a radial distance of 450 of length $9 \mathrm{~m}$.

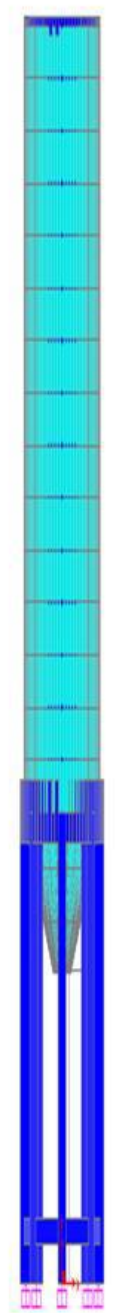

Fig 2. Reinforced Concrete Silo supported on columns with shear walls (MODEL II)
A Plinth beam is provided at the base to provide connectivity between the columns and shear walls. Four Shear walls are provided along with the columns alternatively along the radial direction. Clinker is considered as storage material and live load acting due to storage material is calculated manually and applied uniformly along the height of the silo. A detail of shell elements and frame elements considered for the model making is given in Appendix.

\section{Load Combinations}

The following load combinations are considered for the analysis and design as per

IS 1893 (Part I) -2002.

Where, DL= Dead Load, LL= Live Load

$\mathrm{EQX}, \mathrm{EQy}=$ Earthquake load in $\mathrm{X} \& \mathrm{Y}$ direction respectively.

RSX, RSY = Response Spectrum Load in X \& Y direction respectively.

Table 1. Load combinations as per IS 1893 (Part I) -2002

\begin{tabular}{|c|c|}
\hline Load Combination & Load Factors \\
\hline Gravity Analysis & $1.5(\mathrm{DL}+\mathrm{LL})$ \\
\hline $\begin{array}{l}\text { Equivalent } \quad \text { Static } \\
\text { Analysis }\end{array}$ & $\begin{array}{l}1.2(\mathrm{DL}+\mathrm{IL} \pm \mathrm{EQX}) \\
1.2(\mathrm{DL}+\mathrm{IL} \pm \mathrm{EQY}) \\
1.5(\mathrm{DL} \pm \mathrm{EQX}) \\
1.5(\mathrm{DL} \pm \mathrm{EQY}) \\
0.9 \mathrm{DL} \pm 1.5 \mathrm{EQX} \\
0.9 \mathrm{DL} \pm 1.5 \mathrm{EQY}\end{array}$ \\
\hline $\begin{array}{l}\text { Response } \quad \text { Spectrum } \\
\text { Analysis }\end{array}$ & $\begin{array}{l}1.2(\mathrm{DL}+\mathrm{IL} \pm \mathrm{RSX}) \\
1.2(\mathrm{DL}+\mathrm{IL} \pm \mathrm{RSY}) \\
1.5(\mathrm{DL} \pm \mathrm{RSX}) \\
1.5(\mathrm{DL} \pm \mathrm{RSY}) \\
0.9 \mathrm{DL} \pm 1.5 \mathrm{RSX} \\
0.9 \mathrm{DL} \pm 1.5 \mathrm{RSY}\end{array}$ \\
\hline
\end{tabular}




\section{RESULTS}

Table 2. Lateral Displacement of Model I and Model II for loading 1.5(DL+IL)

\begin{tabular}{|c|c|c|c|c|c|c|c|}
\hline \multirow{3}{*}{ - } & \multirow{3}{*}{ Model Type } & \multirow{3}{*}{$\begin{array}{l}\text { Type of } \\
\text { filling } \\
\text { condition }\end{array}$} & \multicolumn{5}{|c|}{ Loading condition 1.5(DL+IL) } \\
\hline & & & \multicolumn{5}{|c|}{ Height Of Silo (m) } \\
\hline & & & $\mathbf{0 ~ m}$ & $3 \mathrm{~m}$ & $8 \mathrm{~m}$ & $13 \mathrm{~m}$ & $18 \mathrm{~m}$ \\
\hline \multirow{6}{*}{ 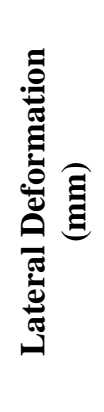 } & \multirow{3}{*}{ MODEL I } & Empty & 0.9 & 1.8 & 2.1 & 2.9 & 4.2 \\
\hline & & Partial & 1.3 & 2.5 & 2.8 & 4 & 5 \\
\hline & & Full & 1.8 & 3.1 & 4 & 5 & 6 \\
\hline & \multirow{3}{*}{ MODEL I } & Empty & 0.1 & 0.1 & 0.2 & 0.3 & 0.3 \\
\hline & & Partial & 0.2 & 0.2 & 0.3 & 0.4 & 0.4 \\
\hline & & Full & 0.2 & 0.2 & 0.3 & 0.4 & 0.4 \\
\hline
\end{tabular}

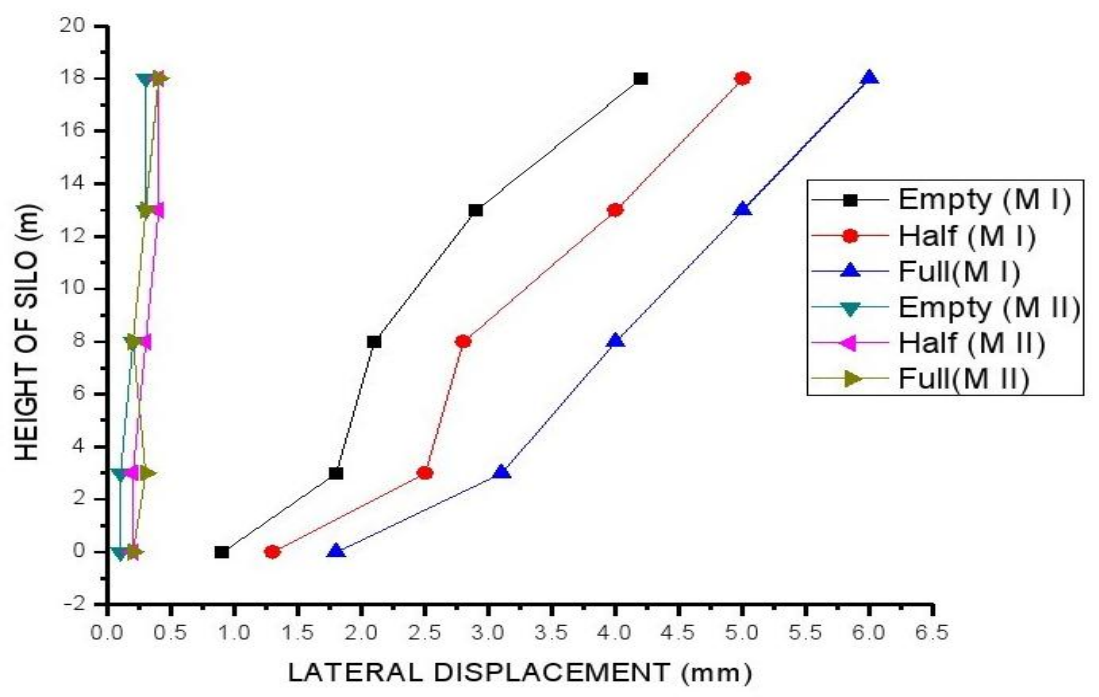

Fig 3 Lateral displacement of Model I and Model II for loading 1.5(DL+IL)

From Table 2 and Fig 3 it is observed that lateral displacement is more at the top for both the models Model I \&Model II. It increases along the height of the silo and also it varies for each type of cases. We can also observe that the lateral deformation decreases on provision of shear wall along with the columns and hence buckling of columns can be reduced.

\section{CONCLUSIONS}

In this study the seismic behavior of reinforced concrete silo supported on shear walls and supported on only columns were analysed for empty, partially filled and fully filled filling conditions. The seismic response of reinforced concrete silo is determined in the form of lateral displacement and were analysed and compared for silo supported on staging with and without shear walls.
Lateral displacement increases with increase in mass and stiffness. Silo with full filled materials experiences high Lateral displacement than Silo with half filled storage material or empty silo. Silo supported on shear wall experiences less Lateral displacement than Silo supported on only columns.

\section{SCOPE FOR FUTURE WORK}

The study may further be carried out for Soil Structure Interaction effect.

$>$ The study may be considered for Silo with only one opening for the movement of vehicles.

$>$ The study may be carried out for other types of Silos and bunkers with different wall thickness. 


\section{REFERENCES}

[1] Adem Dogangun, Zeki Karaca, Ahmet Durmus and Halil Sezen (2009), Cause of Damage and Failures in Silo Structures, Journal of Performance of Constructed Facilities, Vol.23, No. 2, pp ( 65-71).

[2] Alnabuddin L.V. \& Sohrbuddin Ahmad, (1995), Design Forces and Moments in Circular Silos Based on Finite Element Package, Journal of the Civil Engineering division, The Institution of Engineers, Bangladesh, Vol CE23, pp (5988).

[3] Bradely M S, Berrey R.G. and Farnis R.J.(2007), Methods for design of Hoppers, Silos, Bunkers \& Bins for reliable gravity Flow for Pharmaceutical, Food, Mineral and Other applications, The Wolfson Centre of Bulk solids Handling Technology,University of Greenwich,UK, pp ( 213-220).

[4] Carson J. W, Phd and. Jenkyn R.T, (1993), Load Development and Structural Considerations in Silo Design, pp II, pp (1-16)

[5] Flat Tinis and Faith Bazman, (2006) Stiffening of Thin Cylindrical Silo Shell against Buckling Loads, The 12th International Conference On Machine Design And Production8, Turkey, pp (05-08).

[6] Gabriel Perez, (2008),Numerical simulations in granular matter :The discharge of a $2 \mathrm{D}$ silo, Indian Academy of
Sciences,Vol. 70, No. 6, . 989-1007, journal of June, pp (989-1007).

[7] Jofriet J. C. and Kleywegt H. S. (1980), Design Criteria For Hoops Of Concrete

Stave Silos, School of Engineering, Universityof Guelph, Guelph, Ontario NIG 2W1, Can. Agric. Eng. 22,pp ( 9-13).

[8] John W. Carson and Tracy, (200),Silo Failures: Why Do They Happen?, One Technology Drive, Westford, MA, USA, Vol.4, pp ( 499-512).

[9] Mohmed T. Abdel-Fattah, Ian D.Moore, and Tarek T.Abdel-Fattah, (2006) Behavior of elevated concrete Silos filled with saturated Solids, NRC Research Press Web, Vol. 227, pp (33-239).

[10] Nateghi F and Yakhchalian M (2012) Seismic Behavior of Silos with Different Height to Diameter Ratios Considering Granular Material-structure Interaction, Structural Engineering Research Center, Iran, Vol. 25, No. $1, \mathrm{pp}(26-37)$.

\section{BIBILOGRAPHY}

[1] Krishnaraju N, Design of Advanced Reinforced Concrete Structures, 12th Edition, 1988.

[2] Ramamrutam, S. Design of Reinforced Concrete structure, 9th Edition, Aug 1981

\section{APPENDIX}

Table A1. Detailed data of the Reinforced Concrete Silo studied.

\begin{tabular}{|c|c|}
\hline . & OMRF \\
\hline Cylindrical Height $(\mathrm{H})$ & $15 \mathrm{~m}$ \\
\hline Hopper Bottom Height (h) & $5 \mathrm{~m}$ \\
\hline Diameter of Silo (D) & $10 \mathrm{~m}$ \\
\hline $\begin{array}{l}\text { Diameter of Hopper Bottom } \\
\text { (d) }\end{array}$ & $1 \mathrm{~m}$ \\
\hline Column Height & $8 \mathrm{~m}$ \\
\hline Number of Columns & 9 \\
\hline Angle between each Column & $45^{\circ}$ \\
\hline Height of Shear Wall & $9 \mathrm{~m}$ \\
\hline \multicolumn{2}{|c|}{ Material Properties } \\
\hline Grade of concrete & M30 \\
\hline Grade of steel & $\mathrm{Fe} 415$ \\
\hline $\begin{array}{l}\text { Young's modulus M30 } \\
\text { concrete (E) }\end{array}$ & $27.38 \times 10^{6} \mathrm{kN} / \mathrm{m} 2$ \\
\hline $\begin{array}{l}\text { Density of reinforced } \\
\text { concrete }\end{array}$ & $24 \mathrm{kN} / \mathrm{m} 3$ \\
\hline
\end{tabular}

\begin{tabular}{|c|c|}
\hline Density of Clinker (W) & $\begin{array}{c}16.5 \mathrm{kN} / \mathrm{m} 3 \text { (IS } 4995 \text { Part } \\
\text { 1): } 197\end{array}$ \\
\hline $\begin{array}{l}\text { Angle of Friction b/w wall } \\
\text { and storage material }\end{array}$ & $36^{\circ}$ (IS 4995 Part 1): 1974 \\
\hline $\begin{array}{l}\text { Coefficient of wall friction } \\
(\mu)\end{array}$ & 0.7 \\
\hline \multicolumn{2}{|c|}{ Member Properties } \\
\hline \multirow[b]{2}{*}{ Thickness Silo Wall } & $0.2 \mathrm{~m}$ for Cylindrical wall \\
\hline & $\begin{array}{c}0.22 \mathrm{~m} \text { for hopper bottom } \\
\text { wall }\end{array}$ \\
\hline Top Curved Beam size & $0.23 \mathrm{~m} \times 0.35 \mathrm{~m}$ \\
\hline Bottom Curved Beam size & $0.75 \mathrm{mX} 0.35 \mathrm{~m}$ \\
\hline Column Size & $0.5 \mathrm{~m} \times 0.75 \mathrm{~m}$ \\
\hline
\end{tabular}




\section{Equivalent Static method}

Table.A2: Input data of all the structures for equivalent static analysis.

\begin{tabular}{|l|c|}
\hline Zone & II \\
\hline $\begin{array}{l}\text { Zone factor, } Z \text { (Table 2) } \\
\text { IS: 1893 (Part 1 ) -2002 }\end{array}$ & 0.10 \\
\hline $\begin{array}{l}\text { Importance factor, I (Table } \\
\text { 8), } \\
\text { IS: 1893 (Part 4) -2005 }\end{array}$ \\
\hline $\begin{array}{l}\text { Response reduction factor, } R \\
\text { (Table 7), } \\
\text { IS: 1893 (Part 4) -2005 }\end{array}$ \\
\hline $\begin{array}{l}\text { Damping ratio } \\
\end{array}$ \\
\hline
\end{tabular}

\section{Fundamental Natural Period:}

As per IS 1893 ( Part 4) -2005, clause: 14.2, The approximate fundamental natural period of vibration $(T)$ of stack-like structure can be determined by Rayleigh's approximation for fundamental mode of vibration as follows in seconds.

The fundamental time period for Stack-Like Structures $T$ is given by

$\mathrm{T}=\mathrm{CT} \sqrt{ }(\mathrm{W} \mathrm{th}) / \mathrm{Es} \mathrm{g}$

Where,

$\mathrm{CT}=$ Coefficient depending upon the slenderness ratio of the structure given in table 6 of IS 1893 (Part 4),

$\mathrm{Wt}=$ Total weight of the structure including weight of lining contents above base,

$\mathrm{h}=$ Height of the structure above base

Es $=$ Modulus of elasticity of material of structural life

$\mathrm{A}=$ Area of cross section at the base of the structural shell

$\mathrm{g}=$ acceleration due to gravity

$$
\begin{gathered}
T=\frac{2 \pi}{\sqrt{g C \delta}} \\
C \delta=\frac{\sum_{i=1}^{N}(W i \delta i)}{\sum_{i=1}^{N} W i \delta i^{2}}
\end{gathered}
$$

$W i=$ weight lumped at $i$ th location with the weights applied simultaneously with the force

applied horizontally

$\delta i=$ Lateral static deflection under its own lumped weight at $i$ th location

$\mathrm{N}=$ number of locations of lumped weight and

$\mathrm{g}=$ acceleration due to gravity

\section{For Medium Soil Sites,}

$$
\frac{S a}{g}=\left\{\begin{array}{cc}
1+15 T & 0.00 \leq 0.1 \\
2.50 & 0.10 \leq 0.55 \\
\frac{1.00}{T} & 0.55 \leq 4.0
\end{array}\right\}
$$

\section{Design Horizontal Seismic Coefficient, $A h$;}

$$
\begin{aligned}
& A_{h}=\frac{Z I}{2 R} \frac{S a}{g} \\
& A_{h}=\frac{0.10}{2} \times \frac{1.5}{3} \times 2.5=0.0625
\end{aligned}
$$

Design Seismic Base Shear $\mathrm{V}_{\mathrm{B}}=\mathrm{Ah} \mathrm{xW}$

$\mathrm{V}_{\mathrm{B}}=0.0625 \times 30217.50=2015.50$

Vertical Distribution of Base Shear to Different Floor Levels;

The design base shear VB computed is distributed along the height of the building as per following

Expressions

$$
Q i=\mathrm{VB} \frac{W i h i^{2}}{\sum_{j=1}^{n} W j h j^{2}}
$$

